\title{
Analisis Kebijakan Pengembangan Usaha Keluarga Sasaran Program Jaminan Sosial Cilegon Mandiri (KSJSCM)
}

\author{
Yeni Widyastuti ${ }^{1}$ \\ 1Program Studi Administrasi Publik, Fakultas Ilmu Sosial dan Ilmu Politik, Universitas Sultan \\ Ageng Tirtayasa, Serang
}

\begin{abstract}
Mayor Regulation No. 7 of 2017 concerning Jaminan Sosial Cilegon Mandiri. (JSCM) is a program that aims to support the fulfillment of basic needs, education, and family health of poor and disadvantaged people in the form of social assistance. One of the goals of this program is for the family who receives the program able to develop businesses that are managed continuously to improve family welfare. This paper tries to provide recommendations to policy implementers regarding policy alternative to develop and manage bussiness of target group by formulation of policy analysis issues, formulation of objectives, alternative policies, criteria and assessment of alternative policies and recommendations. Method use is qualitative method. Finding of this research is an alternative policy model that involves the public-private partnership in the family (target groups) bussiness development
\end{abstract}

Keywords: alternative policies, target groups, business development

\section{Pendahuluan}

Angka kemiskinan di Provinsi Banten menurut hasil Survei Nasiomal Sosial Ekonomi (Susenas) bulan Maret 2020 sebesar 5,92 persen, mengalami peningkatan sebesar 0,98 poin dibanding periode sebelumnya (September 2019) yang sebesar 4,94 persen (Sumber: Berita Resmi Statistik-Profil Kemiskinan di Banten No. 39/07/36/Th. XIV, 15 Juli 2020). Hal ini sejalan dengan bertambahnya jumlah penduduk miskin sebanyak 134,6 ribu orang dari 641,42 ribu orang pada bulan September 2019 menjadi 75,99 ribu orang pada bulan Maret 2020.
Kota Cilegon merupakan salah satu Kota di Provinsi Banten yang dikenal dengan sebutan Kota Baja, karena di Kota ini banyak berdiri industri-industri besar yang memproduksi baja sebagai produk utama industrinya antara lain PT Krakatau Steel (KS), PT Krakatau Posco, PT Krakatau Steel Persero, PT Tjokro Putra Persada, PT Krakatau Wajatama dan sebagainya. Kota Cilegon mengalami perkembangan yang cukup pesat, seperti berdirinya pabrik-pabrik, kantor-kantor, sarana transportasi, sarana pendidikan, sarana kesehatan, tempat hiburan dan yang lainnya. Kota Cilegon menjadi salah satu wilayah yang 
menjadi tujuan migrasi warga luar daerah yang bertujuan untuk mencari pekerjaan Meskipun demikian tingkat kemiskinan di Kota Cilegon masih sangat tinggi dimana terdapat 14.890 jiwa penduduk miskin pada tahun 2017 dari total jumlah penduduk sebanyak 425.103 jiwa atau mencapai 3,5\%, tahun 2018 turun menjadi 13.964 jiwa atau menjadi $3,25 \%$ dan tahun 2019 menjadi 13.200 jiwa atau 3,03\% (BPS, 2020).

Salah satu upaya yang dilakukan Pemerintah Kota Cilegon untuk menanggulangi kemiskinan adalah mengeluarkan Peraturan Walikota Nomor 7 tahun 2017 tentang Jaminan Sosial Cilegon Mandiri (JSCM) yang bertujuan untuk menunjang pemenuhan kebutuhan dasar, pendidikan, dan kesehatan keluarga dari masyarakat fakir miskin dan tidak mampu dalam bentuk bantuan sosial. Dalam Pasal 5 dinyatakan bahwa JSCM diperuntukan sebagai bantuan bagi KSJSCM dalam menunjang pemenuhan : (a) kebutuhan dasar; (b) pendidikan; dan (c) kesehatan.

Sementara dalam Pasal 10 ayat (b) juga disebutkan bahwa KSJSCM juga berkewajiban untuk mengembangkan usaha yang dikelola secara terus menerus untuk peningkatan kesejahteraan keluarga. Peraturan Walikota Nomor 7 tahun 2017 tentang Jaminan Sosial Masyarakat Cilegon Mandiri (JSCM) dalam pasal 2, bertujuan untuk mendukung program Pemerintah dalam upaya penanggulangan kemiskinan dan salah satu upaya Pemerintah Kota Cilegon untuk menunjang pemenuhan kebutuhan dasar, pendidikan, dan kesehatan keluarga dari masyarakat fakir miskin dan tidak mampu dalam bentuk bantuan sosial. Keluarga Sasaran Jaminan Sosial Cilegon Mandiri selanjutnya disingkat KSJSCM adalah keluarga yang termasuk dalam kelompok masyarakat fakir miskin dan tidak mampu yang teregister dalam Basis Data Terpadu (BDT) yaitu sebuah sistem yang dapat digunakan untuk perencanaan program dan mengidentifikasi nama dan alamat calon penerima bantuan sosial, baik rumah tangga, keluarga, maupun individu berdasarkan pada kriteria-kriteria sosial ekonomi yang ditetapkan oleh pelaksana program.

Penyerapan dana bantuan JSCM secara maksimal ini sayangnya tidak dibarengi dengan upaya pemberdayaan ataupun pembekalan keterampilan yang diberikan oleh pemerintah kepada penerima JSCM. Hal ini dikarenakan program bantuan JSCM masih difokuskan terhadap kebutuhan pendidikan dan kesehatan keluarga.

\section{Metode Penelitian}

Metode penelitian yang digunakan adalah kualitatif (Denzin\&Lincoln, 2011:xviii-xix) Dalam analisis kebijakan publik ketika masalah kebijakan menyangkut keputusan strategis atau kebijakan yang lebih luas, menimbulkan konflik nilai, perasaan, intuisi, penilaian, opini dan sebagainya maka akan dibutuhkan pendekatan kualitatif (Sri Suwitri, dkk.,2016:9.29).

\section{Hasil Penelitian dan Pembahasan \\ 1. Perumusan Masalah}

Pemenuhan jaminan sosial merupakan kewajiban bagi setiap pemerintahan termasuk pemerintah 
daerah. Prioritasnya pada perwujudan keadilan sosial dalam usaha pembangunan masyarakat, kepada anggota masyarakat yang paling miskin, paling lemah dan paling menderita. Kelompok Sasaran Kartu Jaminan Social Cilegon Mandiri (KSJSCM) dapat memanfaatkan dana bantuan JSCM selain untuk pemenuhan kebutuhan dasar, kesehatan dan pendidikan juga dapat menggunakannya untuk pengembangan usaha yang dikelola secara terus menerus untuk meningkatkan kesejahteraan keluarga. Fokus kepada pengembangan usaha ini menjadi penting karena sesuai dengan amanat pasal 10 ayat (b) Perwal Nomor 7 tahun 2017 tentang JSCM yang menyatakan bahwa mengembangkan usaha yang dikelola secara terus menerus untuk peningkatan kesejahteraan keluarga;

\section{Perumusan Tujuan}

Analisis kebijakan bukan menawarkan solusi analitis, namun melihat strategi analisis mana yang harus diterapkan untuk mengembangkan gambaran yang lebih berbeda mengenai proses pembuatan kebijakan (Fischer, et.al, 2019:339) Tujuan analisis kebijakan ini adalah untuk memberikan rekomendasi alternatif kebijakan pengembangan usaha bagi keluarga miskin sebagai Keluarga Sasaran Jaminan Sosial Cilegon Mandiri (KSJSCM) untuk peningkatan kesejahteraan yang dikelola secara terus menerus.

\section{Alternatif Kebijakan}

Penyusunan alternatif kebijakan perlu dilakukan untuk memodifikasi kebijakan yang telah ada. Beberapa alternative yang mungkin untuk dapat dirumuskan sebagai kajian analisis kebijakan Jaminan Sosial Cilegon Mandiri untuk pengembangan usaha dalam rangka peningkatan kesejahteraan keluarga adalah sebagai berikut:

a. Alternatif 1: Validasi Data dan Pengelompokan Data KK yang Memiliki Usaha dan KK yang Belum Memiliki Usaha

Jumlah KK penerima Jaminan Sosial Cilegon Mandiri (JSCM) berdasarkan data dari Dinas Sosial Kota Cilegon tahun 2018 adalah sebanyak 1.871 KK yang tersebar di 8 (delapan) kecamatan yaitu Kecamatan Cibeber, Cilegon, Citangkil, Ciwandan, Gerogol, Jombang Pulomerak dan Purwakarta. Bantuan yang diberikan pemerintah kota Cilegon berupa uang tunai sebesar Rp. 1.000.000/ tahun yang disalurkan setiap semester kepada setiap KSJSCM. Sesuai dengan pasal 5 Perwal Nomor 7 tahun 2017 tentang JSCM bantuan digunakan untuk menunjang pemenuhan kebutuhan dasar, pendidikan dan kesehatan serta dalam pasal 10 ayat (b) penerima wajib mengembangkan usaha yang dikelola secara terus menerus untuk peningkatan kesejahteraan keluarga. Implementasi sampai dengan tahun ke 3 (tiga) dari rencana 5 (lima) tahun pemberlakuan kebijakan ini menunjukkan belum adanya upaya pemberdayaan masyarakat dalam bentuk pengembangan usaha untuk peningkatan 
kesejahteraan masyarakat. Sejauh ini dana bantuan hanya habis untuk pemenuhan kebutuhan dasar KSJSCM. Oleh karenanya perlu dilakukan rencana-rencana sebagai berikut: (i) Pembaharuan data Keluarga Sasaran Jaminan Sosial Cilegon Mandiri (KSJSCM) berbasis pada jumlah KK yang memiliki usaha dan jumlah KK yang belum memiliki usaha; (ii) Identifikasi persoalanpersoalan yang berkaitan dengan pengembangan usaha bagi yang sudah memiliki usaha misalnya apakah kesulitan modal, kesulitan pemasaran, kesulitan pengembangan produk dan lain sebagainya; dan ke (iii) Identifikasi jenis-jenis usaha yang diminati atau diinginkan oleh KK yang belum memiliki usaha atau penyampaian alternatif-alternatif jenis usaha oleh tim pendamping KSJSCM

b. Alternatif 2: Pengelompokan Jenis Usaha Berdasarkan Klaster Wilayah

Secara spesifik dilakukan pengelompokan jenis usaha berdasarkan klaster wilayah, dari delapan kecamatan sasaran. Misalnya dibagi dalam 4 (empat) klaster berdasarkan kedekatan lokasi atau sesuai dengan proporsi penerima bantuan JSCM karena masing-masing kecamatan jumlah KSJSCM nya beragam. Klaster wilayah ini ditujukan untuk memudahkan tim pendampingan dalam pemberdayaan dan penguatan jenis usaha KSJSCM. Hal ini bertujuan agar pendampingan oleh tim pendamping lebih efektif dan lebih merata karena sesuai dengan proporsi KSJSCM.

c. Alternatif 3: Pengelompokan Jenis Usaha Berbasis Produk Usaha

Secara spesifik dilakukan pengelompokan jenis-jenis usaha yang dilakukan oleh KSJSCM. Misalnya Klaster I jenis usaha mayoritas adalah aneka makanan kecil atau makanan khas daerah; Klaster II jenis usaha kerajinan tangan seperti souvenir khas: Klaster III service atau reparasi ringan seperti service komputer, service AC atau alat elektronik lainnya dan sebagainya. Hal ini bertujuan agar pendampingan lebih efektif dan efisien serta lebih dapat terlihat dampaknya bagi KSJSCM.

\section{Penentuan Kriteria}

Ada beberapa beberapa hal dalam menentukan kriteria kebijakan, yakni : (a) Efisiensi dengan kriteria tingkat efisiensi yaitu perbandingan resource dengan manfaat yang optimal; (b) Efektivitas dengan kriteria partisipasi publik, kriteria kerjasama antar instansi; (c) Kelayakan sosial dan budaya dengan kriteria resiko konflik sosial, kriteria keadilan; (d) Kelayakan administrasi beban administrasi dan komitmen institusi; dan ke (e) Ketersediaan Sumberdaya dengan kriteria ketersediaan SDM, sumber dana atau anggaran, peralatan, aturan atau metode kerja. (Patton \& Savicki, 2016; Subarsono,2015) 


\section{Penilaian Alternatif Kebijakan}

Dalam penilaian alternative kebijakan yang memiliki peringkat tertinggi adalah alternative yang mempunyai nilai kumulatif hasil perkalian antara skor dan bobot yang tertinggi. Sebaliknya alternative kebijakan yang memiliki peringkat terendah adalah alternative yang memiliki skor dan bobot yang terendah. Alternatif yang akan direkomendasikan tentunya alternative yang memiliki akumulasi nilai akhir dan paling menguntungkan sebagai alternative pemberdayaan masyarakat Kelompok Sasaran Jaminan Sosial Cilegon Mandiri (KSJSCM) dalam melakukan pengembangan usaha secara terus menerus untuk meningkatkan kesejahteraan keluarga

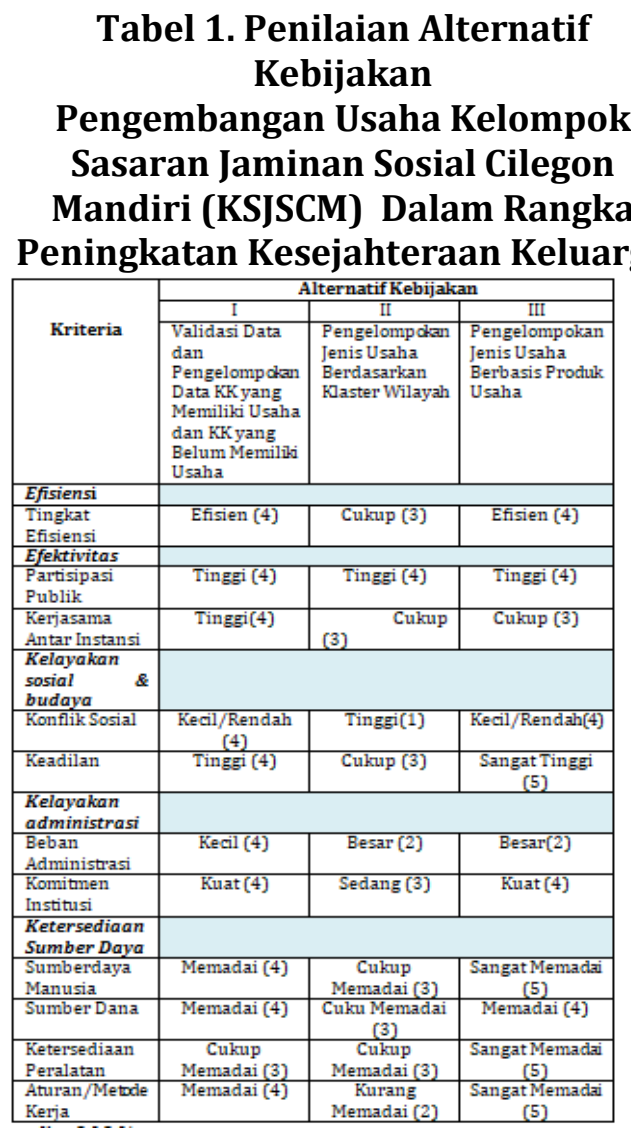

(Penulis, 2020)
Dari tabel di atas tiap-tiap kriteria memberi skor terhadap alternative-alternatif kebijakan sebagai berikut:

1. Kriteria Efisiensi: Tingkat Efisiensi

a. Alternatif I (Validasi Data dan Pengelompokan Data KK yang Memiliki Usaha dan KK yang Belum Memiliki Usaha) skornya adalah efisien (4) karena memang selama ini data KK masih data umum yang belum dipilah sesuai dengan status KK yang memiliki dan tidak memiliki usaha untuk dikembangkan

b. Alternatif

II

(Pengelompokan Jenis Usaha Berdasarkan Klaster Wilayah) skornya adalah cukup (3) karena klaster wilayah ini masih membutuhkan

pertimbangan dari 8 (delapan) kecamatanan yang menjadi KSJSCM apakah sesuai kedekatan wilayah, jumlah penerima bantuan di masing-masing wilayah atau yang lainnya.

c. Alternatif III

(Pengelompokan Jenis

Usaha Berbasis Produk

Usaha) skornya adalah efisien (4) karena dengan jenis-jenis usaha yang telah teridentifikasi maka pendampingan akan menjadi semakin efisien

2. Kriteria Efektivitas : Partisipasi Publik dan Kerjasama antar Instansi 
a. Alternatif I (Validasi Data dan Pengelompokan Data KK yang Memiliki Usaha dan KK yang Belum Memiliki Usaha) skornya adalah tinggi (4) untuk partisipasi publik karena untuk KK yang memiliki usaha ingin adanya pengembangan usahnya sedangkan yang belum memiliki usaha ingin mendapatkan alternative jenis-jenis usaha untuk dikembangkan dan tinggi (4) karena cukup dikoordinir oleh Dinas Sosial saja

b. Alternatif II (Pengelompokan Jenis Usaha Berdasarkan Klaster Wilayah) skornya adalah tinggi (4) untuk partisipasi publik karena antar kecamatan bisa saling bekerjasama untuk kecamatan-kecamatan yang satu klaster dan cukup (3) untuk kerjasama antar instansi karena pola kerjasama yang akan dilakukan harus dikoordinasikan dan disepakati terlebih dahulu

c. Alternatif III (Pengelompokan Jenis Usaha Berbasis Produk Usaha) skornya adalah tinggi (4) untuk partisipasi publik karena masing-masing keluarga sasaran lebih spesifik dalam pengembangan jenis usaha dan skor cukup (3) untuk kerjasama antar instansi karena melibatkan banyak instansi

3. Kriteria Kelayakan Sosial dan Budaya: Resiko Konflik dan Keadilan

a. Alternatif I (Validasi Data dan Pengelompokan Data KK yang Memiliki Usaha dan KK yang Belum Memiliki Usaha) skornya adalah kecil/rendah (4) untuk resiko konflik karena masing-masing $\mathrm{KK}$ memang ingin ada pendampingan atau pemberdayaan karena jika tidak dilakukan khawatir bantuannya akan dikurangi dan skornya cukup (3) untuk keadilan karena bagi KK yang belum memiliki usaha masih harus memikirkan alternative jenis usaha yang bisa dikembangkan

b. Alternatif II (Pengelompokan Jenis Usaha Berdasarkan Klaster Wilayah) skornya adalah tinggi (1) untuk resiko konflik karena penentuan klaster belum tentu memuaskan semua pihak dan kemungkinan ada kecemburuan antar kecamatan yang masuk ke klaster usaha yang peminatnya banyak karena merasa makin banyak pesaing dan cukup (3) untuk keadilan karena merasa ada kesamaan perlakuan ketika ditetapkan dalam satu klaster bersama dengan 
wilayah atau kecamatan lain.

a. Alternatif

(Pengelompokan Jenis

Usaha Berbasis Produk

Usaha) skornya adalah

rendah/kecil (4) untuk resiko konflik karena sudah berbasis jenis-jenis usaha yang memang selama ini sudah dijalankan oleh KK yang bersangkutan dan skornya sangat tinggi (5) untuk keadilan karena sudah sesuai dengan bidang usaha yang selama ini digeluti dan ingin dikembangkan agar keberlangsungan usaha terus berjalan

4. Kriteria

Administrasi:

Kelayakan Administrasi dan Komitmen Institusi

a. Alternatif I (Validasi Data dan Pengelompokan Data KK yang Memiliki Usaha dan KK yang Belum Memiliki Usaha) skornya adalah rendah (4) untuk beban administrasi karena cukup dikoordinir oleh Dinas Sosial dengan memberi kriteria tambahan bagi KSJSCM tentang apakah KK memiliki usaha atau tidak sedangkan untuk komitmen institusi skornya tinggi (4) karena memang amanah Perwal nomor 7 tahun 2017 tentang Jaminan Sosial Cilegon Mandiri (JSCM) pelaksana utamanya atau koordinatornya adalah Dinas Sosial

b. Alternatif II (Pengelompokan Jenis Usaha Berdasarkan Klaster Wilayah) skornya adalah besar (2) untuk beban administrative karena untuk pembentukan kluster harus berkoordinasi dengan kecamatan lain dan skor sedang (3) untuk komitmen institusi karena berkenaan dengan beberapa beberapa kecamatan yang harus berkoordinasi

c. Alternatif III Pengelompokan Jenis Usaha Berbasis Produk Usaha skornya adalah besar (2) untuk beban administrasi karena dalam pengelompokan jenis-jenis usaha diperlukan waktu, tenaga dan dana yang cukup besar untuk pendataan dan pemilahan jenis-jenis usaha sedangkan untuk komitmen institusi skornya kuat atau tinggi (4) karena orientasi kebijakan ini mengharapkan

keberhasilan pelaksnaan program atau dampak yang lebih terasa di masyarakat.

5. Kriteria Ketersediaan Sumber Daya: Sumberdaya Manusia, Sumber Dana, Ketersediaan Peralatan dan Aturan/Metode Kerja 
a. Alternatif I (Validasi Data dan Pengelompokan Data KK yang Memiliki Usaha dan KK yang Belum Memiliki Usaha) skornya adalah memadai (4) untuk sumberdaya manusia dan memadai (4) juga utuk sumber dana, karena memang sudah masuk tahun ketiga pelaksanaan kebijakan JSCM ini sedangkan untuk ketersediaan peralatan skornya cukup memadai (3) karena sedikit merubah pola yaitu mengumpulkan data tambahan tentang jenis usaha jadi bisa saja operator JSCM atau pencetakan kartu JSCM yang perlu dirubah sedangkan untuk aturan atau metode kerja skornya memadai (4) karena memang sudah masuk dalam pelaksanaan tahun ke tiga.

b. Alternatif II (Pengelompokan Jenis Usaha Berdasarkan Klaster Wilayah) skornya adalah cukup memadai (3) untuk sumber daya manusia karena mesti ada kejelasan pembagian klaster seperti apa dan berapa yang harus disiapkan personelnya, sedangkan untuk sumber dana skornya juga cukup memadai (3) karena masing-masing klaster pembagiannya belum diketahui seperti apa kemudian untuk peralatan skornya adalah cukup memadai (3) karena masing-masing klaster beban peralatannya berbeda-beda dan kesiapannya juga berbedabeda dan untuk subkriteria metode kerja juga skornya kurang memadai (2) karena belum disepakati bagaimana metode kerja setelah terbentuknya klaster

c. Alternatif III (Pengelompokan Jenis Usaha Berbasis Produk Usaha) skornya adalah sangat memadai (5) untuk sumberdaya manusia karena masingmasing instansi yang terlibat mempersiapkan SDM, dukungan dana skornya juga memadai (4) karena masing-masing instansi mempersiapkan anggaran untuk jenis usaha tertentu atau sudah spesifik; sedangkan untuk peralatan skornya juga sangat memadai (5) karena banyak instansi yang dilibatkan sehingga banyak peralatan yang tersedia untuk pengembangan jenis usaha serta skor sangat memadai (5) untuk metode kerja karena sudah lebih spesifik jenis usahanya apa dan pengembangannya bagaimana.

Dari pemberian skor tersebut kemudian ditentukan bobot 
penilaiannya terhadap masingmasing alternative berdasarkan kriteria-kriteria yang telah ditentukan. Penentuan bobot tiaptiap kriteria adalah sebagai berikut:

a. Efisiensi diberi bobot $10 \%$

b. Efektivitas diberi bobot $20 \%$ yang dibagi dalam dua sub kriteria yaitu Partisipasi Publik sebesar $10 \%$ dan Kerjasama antar Instansi sebesar $10 \%$

c. Kelayakan Sosial dan Budaya diberi bobot sebesar 15\% yang dibagi dalam dua sub kriteria yaitu Resiko Sosial sebesar $10 \%$ dan Keadilan sebesar $5 \%$

d. Kelayakan Administrasi diberi bobot $15 \%$ dibagi dalam dua sub kriteria yaitu Beban Administrasi sebesar 10\% dan Komitmen Institusi sebesar $5 \%$

e. Ketersediaan Sumber Dayadiberi bobot $40 \%$ yang dibagi dalam empat sub kriteria yaitu sumber daya manusia sebesar $10 \%$, sumber dana sebesar $20 \%$; Peralatan sebesar $5 \%$ dan aturan atau metode kerja sebesar 5\%.

Setelah ditemukan bobot dari masing-masing kriteria maka dilakukan penilaian dengan mengalikan antara skor dan bobot sehinggga ditemukan nilai dari masing-masing alternative sebagaimana tabel berikut :
Tabel 2. Hasil Pembobotan dan Penilaian terhadap Alternatif Kebijakan

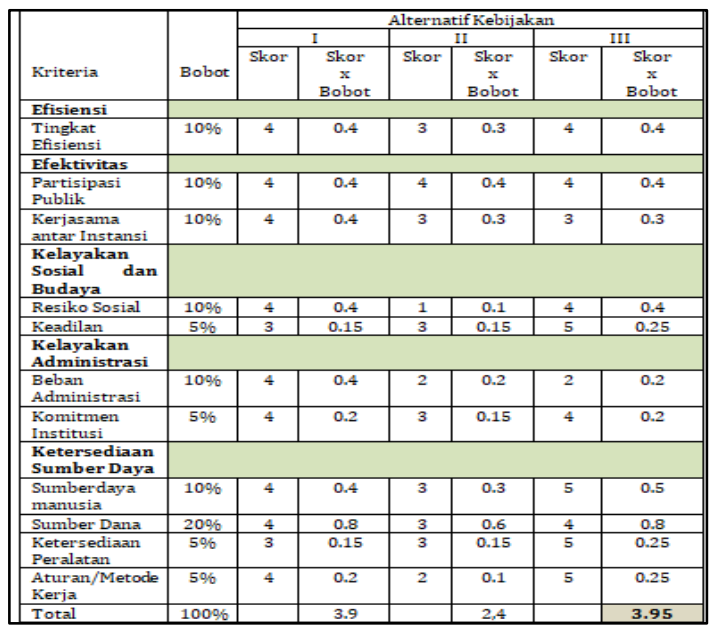

(Penulis, 2020)

Berdasarkan tabel 2 di atas dapat ditemukan nilai dari alternativealternatif adalah sebagai berikut:

1) Alternatif I (Validasi Data dan Pengelompokan Data KK yang Memiliki Usaha dan KK yang Belum Memiliki Usaha) dengan total penilaian 3.9

2) Alternatif II (Pengelompokan Jenis Usaha Berdasarkan Klaster Wilayah) dengan total penilaian 2.4

3) Alternatif III (Pengelompokan Jenis Usaha Berbasis Produk Usaha) dengan total penilaian 3.95

Dalam rekapitulasi hasil pembobotan terhadap seluruh alternative kebijakan sebagaimana ditunjukkan dalam tabel 2 di atas maka dapat disusun peringkat alternative kebijakan yaitu Peringkat Pertama Alternatif III yaitu Pengelompokan Jenis Usaha Berbasis Produk Usaha dengan jumlah nilai tertinggi 3.95; Peringkat Kedua Alternatif I yaitu Validasi Data dan Pengelompokan Data KK yang 
Memiliki Usaha dan KK yang Belum Memiliki Usaha dengan jumlah nilai 3.9 dan Peringkat III adalah Alternatif II Pengelompokan Jenis Usaha Berdasarkan Klaster Wilayah dengan jumlah nilai 2.4.

6. Rekomendasi Kebijakan

Berdasarkan pertimbangan dari sisi keuntungan dan kelemahan dari ketiga alternative yang dianalisis, jika dilihat dari tujuan analisis yaitu untuk memberikan rekomendasi alternatif kebijakan pengembangan usaha bagi keluarga miskin sebagai Keluarga Sasaran Jaminan Sosial Cilegon Mandiri (KSJSCM) untuk peningkatan kesejahteraan yang dikelola secara terus menerus, telah dilakukan penilaian terhadap tiga alternative yang ditawarkan dan dari penilaian-penilaian alternative tersebut didapatkan bahwa Alternatif III Pengelompokan Jenis Usaha Berbasis Produk Usaha merupakan alternative dengan jumlah kumulatif tertinggi dan paling menguntungkan. Oleh karenanya dari analisis Pengembangan Usaha Keluarga Sasaran Jaminan Sosial Cilegon Mandiri (KSJSCM) dalam rangka Peningkatan Kesejahteraan Keluarga dapat diberikan rekomendasi bahwa Pengelompokan Jenis Usaha Berbasis Produk Usaha bagi KSJSCM merupakan scenario terbaik untuk memberikan lebih besar manfaat dan memberdayakan KSJSCM dalam pengembangan usaha sesuai dengan kondisi dan kemampuannya masingmasing.

\section{Kesimpulan}

\section{Rencana Implementasi Kebijakan}

Agar alternative kebijakan yang direkomendasikan ini dapat berjalan dengan baik dalam implementasinya maka perlu dilakukan beberapa langkah aksi sebagai rencana implementasi kebijakan. Langkah aksi tersebut antara lain:

Pertama: Dinas Sosial melakukan koordinasi dengan dinasdinas seperti Dinas Koperasi dan UMKM untuk pengembangan jenisjenis usaha rumah tangga atau usaha kecil dan menengah, melakukan koordinasi juga dengan Dinas Pertanian untuk pelatihan ketrampilan bertanam secara holtikultura atau hidroponik, atau keterampilan beternak, yang juga memungkinkan sebagai alternatif jenis usaha.

Kedua, Dinas Sosial melakukan model kerjasama One Village One Product (OVOP) bekerjasama dengan dinas-dinas terkait atau dengan private sector untuk membantu pemasaran produk usaha. Misalnya melalui retailretail seperti Indomaret, Alfamart, Hypermart dan Transmart. Kemitraan publik-swasta mengambil berbagai bentuk antara lain investasi publik yang signifikan dalam infrastruktur (misalnya pusat perbelanjaan) dan pengembangan inovasi bahkan produk baru (Reeves,2003; Rosenau,2000 dalam Moran,et.al.2016:229).

Ketiga, Pemerintah Kota Cilegon perlu melaksanakan koordinasi dan sinkronisasi dengan seluruh instansi yang berhubungan dengan pengembangan usaha Kelompok Sasaran JSCM khususnya dan warga miskin, terlemah dan yang paling menderita secara umum, karena persoalan kemiskinan memerlukan usaha yang terus menerus dari seluruh elemen mulai dari masyarakat, sektor swasta, pemerintah daerah dan pemerintah pusat. 


\section{Daftar Referensi}

Denzin, N. K. \& Y. S. L. (Ed). (2011). The Sage Handbook of Qualitative Research 1 (Edisi Ketiga). Pustaka Pelajar.

Rosma, F. (2020). Implementasi Peraturan Wali Kota Cilegon Nomor 7 Tahun 2017 Tentang Program Jaminan Sosial Cilegon Mandiri (JSCM) Di Kecamatan Citangkil Kota Cilegon. Sultan Ageng Tirtayasa University.

Fischer, Frank., Gerald J.Miller., M. S. S. (2019). Handbook Analisis Kebijakan Publik: Teori, Politik dan Metode. Nusa Media.

Moran, Michael.,,Martin Rein., R. E. G. (2016). Handbook Kebijakan Publik. Nusa Media.

Patton, C. V. \& D. S. S. (2016). Basics Method of Policy Analysis and Planning - Third Edition. Routledge - Taylor and Francis Group.

Subarsono, A. (2015). Analisis Kebijakan Publik: Konsep, Teori dan Aplikasi (Cetakan Ke-7). Pustaka Pelajar.

Suwitri, Sri., Hartuti Purnaweni., K. (2016). Analisis Kebijakan Publik (Buku Materi Pokok MAP5301/4 sks/Modul 1-12). Universitas Terbuka.

Dokumen dan Peraturan Perundangan:

Statistik, B. P. (2020). Berita Resmi Statistik-Profil Kemiskinan di Banten No. 39/07/36/Th. XIV, 15 Juli 2020.
Peraturan Walikota Cilegon Nomor 7

Tahun 2017 tentang Jaminan

Sosial Cilegon Mandiri, (2017).

Kota Cilegon dalam Angka tahun 2019. (2019). 